Magdalena Paul

Sylwia Piekarska

Koło Naukowe Instytutu Informacji Naukowej

i Studiów Bibliologicznych

Uniwersytet Warszawski

\title{
Idealna biblioteka uniwersytecka na podstawie badań oczekiwań studentów Uniwersytetu Warszawskiego
}

\section{Jakość w teorii zarządzania i bibliotekoznawstwa ${ }^{1}$}

Termin ,jakość” (ang. quality) ma długą historię w teorii zarządzania. Po raz pierwszy użył go twórca naukowego nurtu zarządzania, Fryderyk Taylor, w 1911 r. w pracy pt.: „The principles of scientific management”. Taylor pisał, że „zarządzający powinni nie tylko planować i nadzorować pracę, lecz także powinni badać jakość wyrobów" "Na początku XX wieku jakość była więc utożsamiana $\mathrm{z}$ techniczną doskonałością produktu. Obecnie pojęcie jakości jest rozumiane bardzo szeroko i może być rozpatrywane w kategoriach filozoficznych, technicznych, ekonomicznych i marketingowych ${ }^{3}$. Wyróżnia się dwie główne grupy definicji tego terminu. Pierwsza z nich kładzie nacisk na zgodność ze standardami (specyfikacja). W tym rozumieniu, aby osiagnąć jakość, należy sformułować szczegółowe standardy, normy, a następnie dokładnie ich przestrzegać, kontrolować wykonanie usług i wykrywać oraz usuwać ewentualne błędy ${ }^{4}$.

Druga grupa definicji postrzega jakość jako ,całokształt cech i charakterystyk produktu lub usługi posiadających zdolność do zaspokojenia wyrażonych lub ukrytych potrzeb, oczekiwań i wymagań klientów"s.

${ }^{1}$ Dwa pierwsze fragmenty artykułu pochodzą z pracy dyplomowej Magdaleny Paul pt.: „Jakość usług publicznych warszawskich bibliotek multimedialnych w ocenie młodzieży - badanie metodą SERVQUAL", przygotowanej w Instytucie Informacji Naukowej i Studiów Bibliologicznych UW pod kierunkiem doktora Mariusza Luterka.

2 Głowacka E.: Studium zastosowania kompleksowego zarzqdzania jakościq (TQM) w bibliotekoznawstwie i informacji naukowej. Toruń: Wydawnictwo UMK, 2000, s. 17.

3 Sidor M. W.: Jakość ustug bibliotecznych: badanie metoda SERVQUAL. Warszawa: Wydawnictwo SBP, 2005, s. 17.

4 Zybert E. B.: Jakość w działalności bibliotek: oceny, pomiary, narzędzia. Warszawa: CEBID, 2007, s. 22.

5 Tamże, s. 23. 
Podejście to nazywane jest rynkowym, a jego cechą charakterystyczną jest opisywanie jakości w kategoriach użyteczności dla nabywcy (ang. fitness for use). To do nabywcy należy prawo określania standardów i wymagań, którymi powinna kierować się organizacja ${ }^{6}$. W tym rozumieniu jakość może zostać osiagnięta poprzez poznanie potrzeb klientów oraz włączenie tej wiedzy w plany działania organizacji i kulturę organizacyjną, co umożliwia dostarczenie usług zgodnych z oczekiwaniami klientów. Obecnie zadowolenie użytkownika lub klienta (satysfakcja) wydaje się centralnym punktem wszelkich działań organizacji i jednocześnie miernikiem jakości.

Pojęcia satysfakcji i jakości są niekiedy utożsamiane. Różnica pomiędzy nimi polega na tym, że jakość jest długotrwałą ogólną oceną, a satysfakcja jednorazową, krótkotrwałą oceną danej usługi. „Ponadto, pomiar jakości usług jest narzędziem planowania strategicznego, podczas gdy ocena satysfakcji klienta jest narzędziem diagnozy"7 . W bibliotekoznawstwie pojęcia „jakość” po raz pierwszy użył Richard Orr w 1973 r., definiując jakość jako zaspokajanie potrzeb użytkowników. Jeszcze przed tym, w latach sześćdziesiątych, jakość utożsamiana była $\mathrm{z}$ efektywnym realizowaniem procesów bibliotecznych i informacyjnych. W latach siedemdziesiątych i osiemdziesiątych skupiono się na jakości informacji $i$ baz danych. Próbowano również wypracować wskaźniki efektywności bibliotek. W latach dziewięćdziesiątych pojęcie jakości na powrót odnoszono do zaspokajania obecnych i przewidywanych potrzeb użytkowników bibliotek i ośrodków informacji ${ }^{8}$.

Pod koniec lat dziewięćdziesiątych i na początku XXI w. wzrosło zainteresowanie oceną zadań wykonywanych w bibliotekach. Spowodowane było to szeregiem czynników:

a) dążeniem do wydajności i pełnego zaspokajania potrzeb użytkowników i decydentów, których opinie wpływają na wizerunek biblioteki i mogą współdecydować o przyznawanych funduszach;

b) koniecznością rozliczania się przed organami finansującymi z zagospodarowania funduszy i dowodzenia, że zasoby zostały optymalnie wykorzystane;

c) wymogami oceny bibliotek zgodnie $\mathrm{z}$ lokalnymi, krajowymi lub międzynarodowymi przepisami;

d) działaniami akredytacyjnymi dla bibliotek, bibliotekarzy i pracowników informacyjnych ${ }^{9}$.

6 Sidor M. W.: Jakość ustug bibliotecznych: badanie metoda SERVQUAL. Warszawa: Wydawnictwo SBP, 2005, s. 18.

7 Tamże, s. 43.

8 Tamże, s. 33.

9 Zybert E. B.: Jakość..., s. 16-17. 


\section{Metoda oceny jakości usług SERVQUAL}

W latach 80. XX w. zainteresowanie klientem oraz jakością produktów i usług znacznie wzrosło w przemyśle, instytucjach usługowych i w środowisku akademickim. W wyniku tego w 1985 r. A. Parasuman, Leonard Berry i Valarie Zeithalm wydali pracę A Conceptual Model of Service Quality, a w 1988 r. opublikowali kolejne opracowanie, w którym rozwinęli koncepcję pomiaru jakości usług i nadali jej nazwę SERVQUAL ${ }^{10}$. Metoda ta była wykorzystana $\mathrm{w}$ badaniach wielu instytucji usługowych, m.in. związanych $\mathrm{z}$ ochroną zdrowia, bankowością, naprawą urządzeń ${ }^{11}$. Parasuman, Berry i Zeithalm opracowali model różnic między oczekiwanym a faktycznym poziomem jakości usługi z perspektywy klienta (ang. The Gaps Model of Service Quality) ${ }^{12}$. W ramach modelu wyróżnili następujące różnice, nazywane lukami:

1. Różnica pomiędzy oczekiwaniami klienta a postrzeganiem tych oczekiwań przez zarządzających;

2. Różnica pomiędzy postrzeganiem przez zarządzających oczekiwań klientów a specyfikacją usług (standaryzacja)

3. Różnica pomiędzy specyfikacją jakości usług a usługą aktualnie dostarczoną

4. Różnica pomiędzy usługą dostarczoną a informacją przekazaną klientowi na temat tej usługi

5. Różnica pomiędzy oczekiwaniami klienta a postrzeganymi przez niego usługami ${ }^{13}$.

Pierwsze cztery luki odnoszą się do rozbieżności występujących wewnątrz organizacji, ostatnia natomiast dotyczy różnicy między oczekiwanym przez klienta a postrzeganym poziomem usług ${ }^{14}$. Autorzy metody SERVQUAL ustalili cztery podstawowe czynniki, kształtujące oczekiwania klientów, tj.: komunikację ustną, potrzeby osobiste, wcześniejsze doświadczenia i umiejętność komunikowania się usłu-godawców. Zwrócili też uwagę na to, że klienci używają podobnych kryteriów w ocenie jakości usług bez względu na typ usługi. Kryteria te nazwali determinantami postrzegania jakości usług $^{15}$.

${ }^{10}$ Sidor M. W.: Jakość ..., s. 60.

${ }^{11}$ Nitecki D. A.: SERVQUAL: Measuring Service Quality in Academic Libraries [online] p. 1. ARL, Washington 1997. Dostępny w Internecie: http://www.arl.org/ bm doc/servqual-2.pdf [data dostępu: 03 lutego 2012].

12 Głowacka E.: Studium..., s. 64.

${ }^{13}$ Cyt. za: Sidor M. W.: Jakość..., s. 61.

${ }^{14}$ Zybert E. B.: Jakość..., s. 69.

${ }^{15}$ Sidor M. W.: Jakość..., s. 61. 


\section{Rys. 1. Determinanty postrzegania usług}

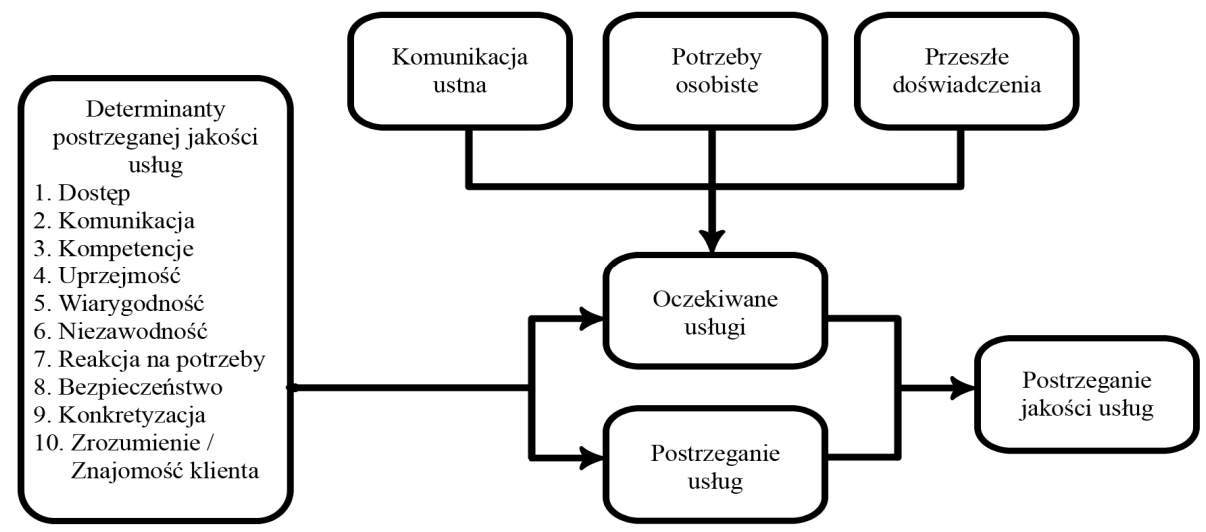

Źródło: M. W. Sidor: Jakość ustug bibliotecznych: badanie metoda SERVQUAL. Warszawa: Wydaw. SBP, 2005, s. 61.

Początkowo wyznaczyli 10 determinantów jakości usług, natomiast po licznych badaniach ich liczba została zredukowana do pięciu:

1. Niezawodność - zdolność do wykonywania obiecanej usługi rzetelnie i dokładnie;

2. Reakcja - chęć pomagania klientom i szybka realizacja usługi;

3. Fachowość - wiedza i uprzejmość pracowników i ich zdolności komunikacyjne, umiejętność wzbudzania zaufania u klientów;

4. Empatia - troska oraz zindywidualizowane podejście do klienta;

5. Konkretyzacja - wygląd fizyczny urządzeń, sprzętu, personelu i materiałów informacyjnych ${ }^{16}$.

Kwestionariusz SERVQUAL, służący do pomiaru jakości usług, pierwotnie składał się z dwóch części. Pierwsza z nich mierzyła oczekiwania klientów, druga natomiast percepcje jakości w konkretnej instytucji. Sformułowano 22 twierdzenia odnoszące się zarówno do oczekiwań, jak i percepcji. Stwierdzenia te zgrupowano w pięciu wymiarach odpowiadających determinantom postrzegania usług. W wyniku licznych badań i doświadczeń

${ }^{16}$ Coleman V. [et al.]: Toward a TQM Paradigm: Using SERVQUAL to Measure Library Service Quality, College \& Research Libraries [online], No. 58 (3) p. 238. ACRL, Chicago 1997. Dostępny w Internecie: http://crl.acrl.org/content/58/3/ 237.full.pdf [data dostępu: 03 lutego 2012].

60 
autorzy wielokrotnie modyfikowali oraz rozbudowywali kwestionariusz ${ }^{17}$.

Metoda SERVQUAL znalazła szerokie zastosowanie w badaniach jakości usług bibliotecznych w wielu krajach: USA, Kanadzie, Nowej Zelandii, Australii, Chinach a także niektórych krajach Europy i Afryki ${ }^{18}$. W Polsce, wykorzystując tę metodę, Maria Wanda Sidor przeprowadziła badania bibliotek naukowych niepaństwowych szkół wyższych ${ }^{19}$.

\section{Biblioteka Uniwersytetu Warszawskiego}

System biblioteczno-informacyjny Uniwersytetu Warszawskiego tworzą: biblioteka główna pod nazwą Biblioteka Uniwersytecka w Warszawie (BUW) oraz biblioteki jednostek organizacyjnych UW (wydziałowe, instytutowe, katedralne) ${ }^{20}$. BUW pełni funkcję centralnego ośrodka informacji naukowej Uniwersytetu Warszawskiego jest biblioteką naukową o charakterze publicznym ${ }^{21}$. Do czasu wybudowania nowego gmachu mieściła się w Collegium Novum w kampusie centralnym przy Krakowskim Przedmieściu. Od 15 grudnia 1999 roku cała biblioteka mieści się na Powiślu. Jej budynek zaprojektowano według projektu Marka Budzyńskiego i Zbigniewa Badowskiego ${ }^{22}$.

Według Sprawozdania BUW za rok 2010 zbiory Biblioteki liczyły 3013030 jednostek ewidencyjnych, w tym:

- 1878279 jednostek ewidencyjnych książek,

- 695065 jednostek ewidencyjnych czasopism,

- 393761 jednostek ewidencyjnych zbiorów specjalnych,

- 45925 jednostek ewidencyjnych księgozbioru dydaktycznego ${ }^{23}$.

${ }^{17}$ Sidor M. W.: Jakość ustug bibliotecznych: metoda SERVQUAL. [W:] Dobra biblioteka publiczna - czyli jaka?: studia i materiaty. Pod red. Anny Wiśniewskiej i Artura Paszko. Kraków: Wojewódzka Biblioteka Publiczna, 2006, s. 61.

${ }^{18}$ Sidor M. W.: Jakość ustug bibliotecznych: badanie metoda SERVQUAL..., s. 91.

${ }^{19}$ Tamże.

${ }^{20}$ Regulamin systemu biblioteczno-informacyjnego UW [online]. Dostępny w Internecie: http://www.buw.uw.edu.pl/index.php?option=com_content\&task=view \&id=325\&Itemid=61 [data dostępu: 12 maja 2012].

${ }^{21}$ Regulamin korzystania ze zbiorów [online]. Dostępny w Internecie: http://www.buw.uw.edu.pl/index.php?option=com_content\&task=view\&id=120\&Ite mid=83 [Data dostępu: 12 maja 2012].

${ }^{22}$ Biblioteka Uniwersytecka $w$ Warszawie [online]. Dostępny w Internecie: http://pl.wikipedia.org/wiki/Biblioteka_Uniwersytetu_Warszawskiego [data dostępu: 12 maja 2012].

${ }^{23}$ Sprawozdanie Biblioteki Uniwersyteckiej $w$ Warszawie i bibliotek wydziałowych UW za rok 2010 [online]. BUW, Warszawa 2011, s. 45. Dostępny w Internecie: 
Na koniec 2010 roku w obszarze wolnego dostępu znajdowało się 429057 woluminów, w tym całość księgozbioru dydaktycznego. Zbiory w wolnym dostępie ustawione są według Klasyfikacji Biblioteki Kongresu ${ }^{24}$. W 2010 r. BUW odwiedziło 75435 czytelników. Statystyczny czytelnik odwiedził Bibliotekę blisko dziesięć razy ${ }^{25}$. W 2010 roku wypożyczono poza Bibliotekę czytelnikom indywidualnym 537143 woluminów, z tego 87,2\% z wolnego dostępu ${ }^{26}$. Użytkownicy BUW mają dostęp do ponad 50 baz pełnotekstowych oraz abstraktowych. W 2010 roku odnotowano 748301 pobrań pełnych tekstów ze zbiorów dostępnych online ${ }^{27}$.

Liczba udzielonych informacji bibliotecznych, bibliograficznych i rzeczowych wyniosła w 2010 r. 127 377. Zarejestrowano 1152813 wejść do katalogu online bibliotek UW, to jest średnio 96068 wejść miesięcznie i 3158 wejść na dobę. Na stronie domowej BUW odnotowano 1465738 odwiedzin wykonanych przez 692414 unikatowych gości, którzy otworzyli 13604466 stron $^{28}$.

Biblioteka Uniwersytecka wraz z bibliotekami wydziałowymi gromadzi liczne dane statystyczne, które publikowane są w sprawozdaniach rocznych.

\section{Wyniki ankiety wykonanej metodą oceny jakości usług SERVQUAL}

Celem badań było przedstawienie oczekiwań studentów Uniwersytetu Warszawskiego dotyczących jakości usług biblioteki uniwersyteckiej. Ankieta została przeprowadzona online za pośrednictwem portalu moje-ankiety.pl. W badaniu wzięło udział 118 studentów UW, 85 kobiet i 33 mężczyzn (72\% kobiet i $28 \%$ mężczyzn).

http://www.buw.uw.edu.pl/images/BUW_PDF/sprawozdanie/spraw_ [data dostępu: 12 maja 2012].

buw_2010.pdf

${ }^{24}$ Tamże, s. 64.

${ }^{25}$ Tamże, s. 72.

${ }^{26}$ Tamże, s. 74.

${ }^{27}$ Tamże, s. 76.

${ }^{28}$ Tamże, s. 80. 
Wykr. 1. Płeć respondentów

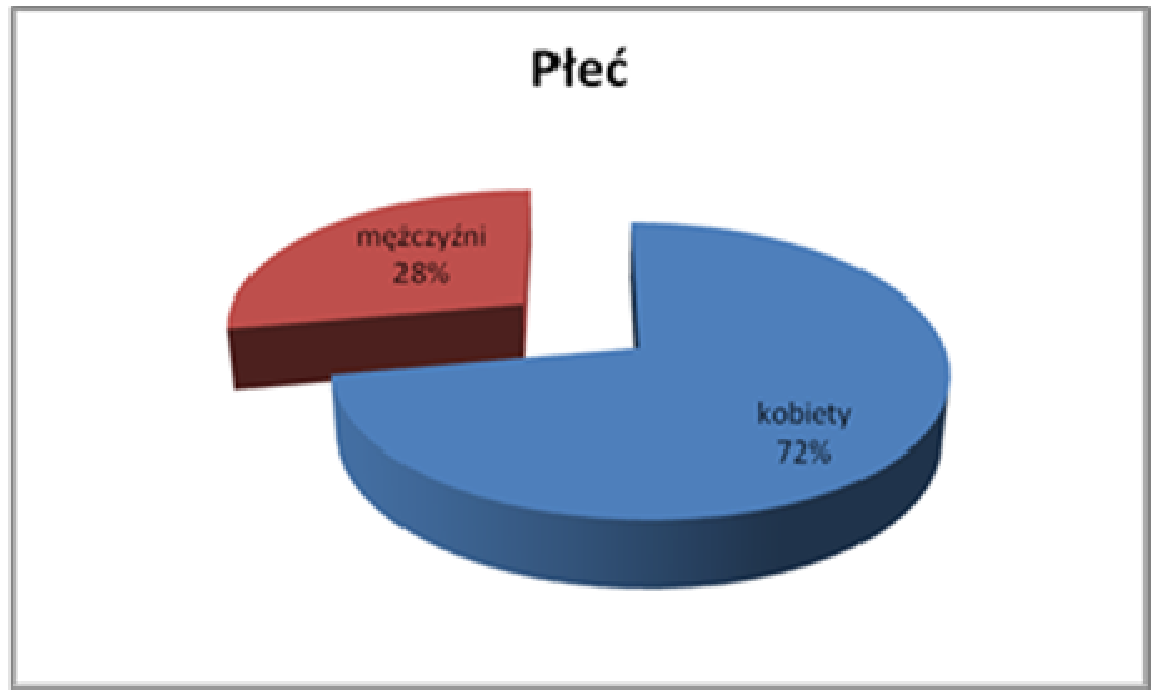

Źródło: opracowanie własne.

Średni wiek respondentów to 22 lata. Ankietę wypełnili studenci studiów licencjackich dziennych (87 osób), licencjackich zaocznych - (1 osoba), magisterskich dziennych ( 25 respondentów), magisterskich zaocznych ( 3 badanych), wieczorowych (2 ankietowani) oraz dwie osoby studiujące równolegle dwa kierunki.

Wykr. 2. Rodzaj studiów respondentów

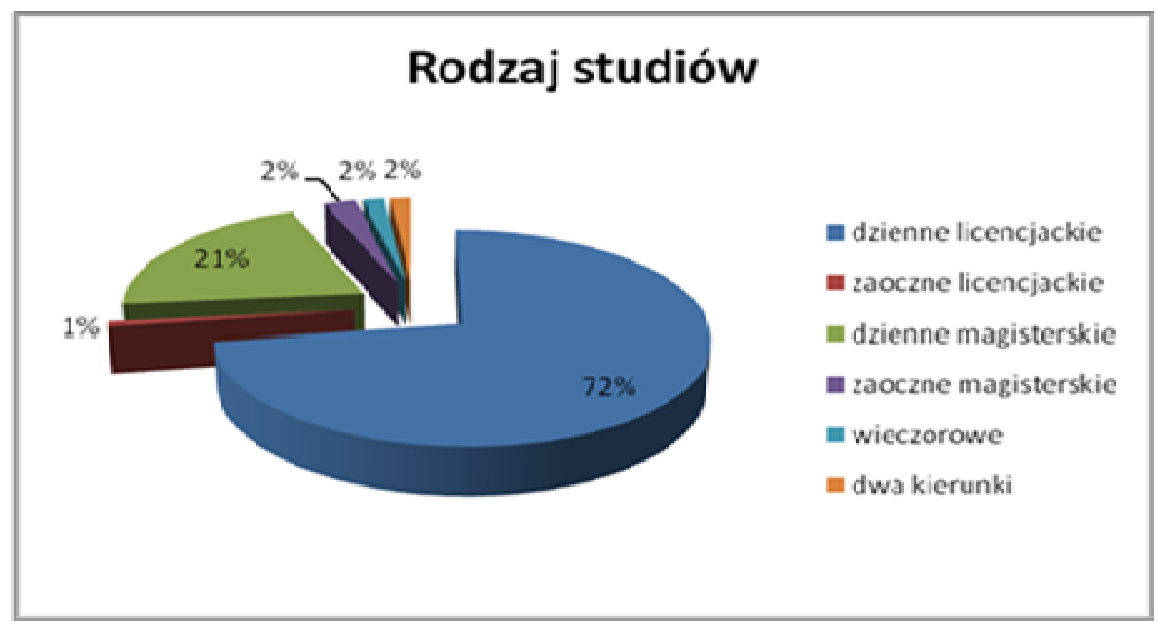

Źródło: opracowanie własne. 
Na pierwszym roku studiów licencjackich było 19 osób; na drugim 42, zaś na trzecim - 41 osób. Studenci studiów magisterskich byli mniej liczni: na pierwszym roku studiowało 11 osób, a na drugim - 5 badanych.

\section{Wykr. 3. Rok studiów respondentów}

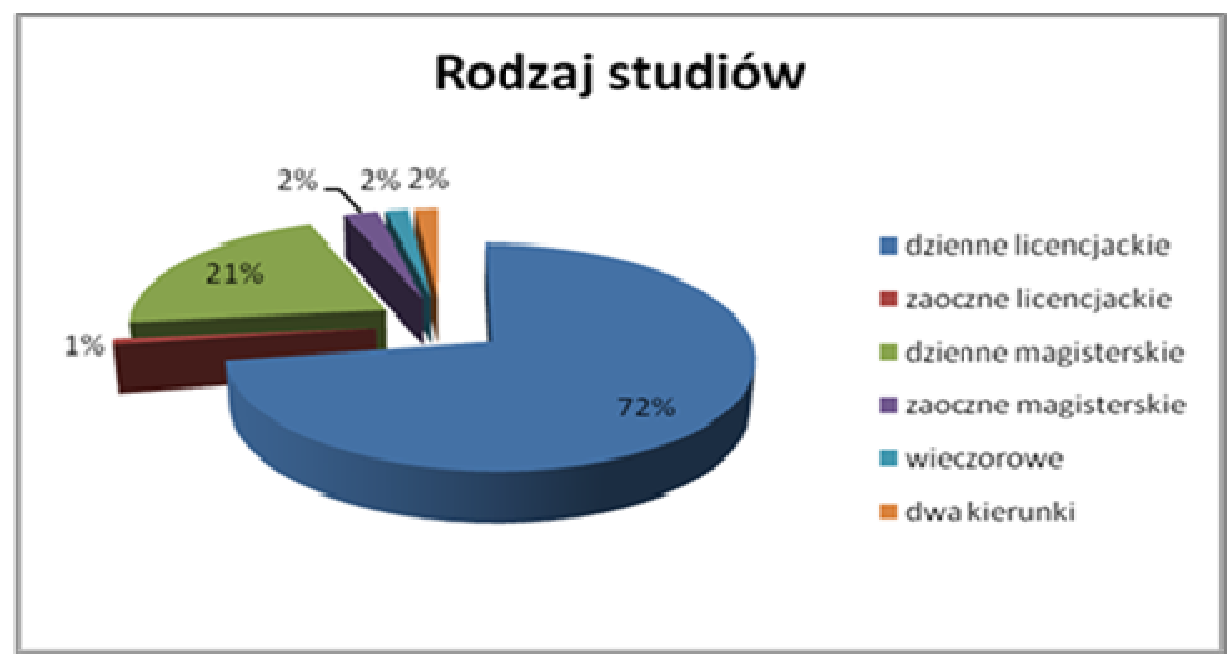

Źródło: opracowanie własne.

Wśród respondentów 52 osoby tj. $44 \%$ to studenci informacji naukowej i bibliotekoznawstwa. Pozostali respondenci, czyli 56\%, to studenci takich kierunków jak: prawo, europeistyka, filologie polska, angielska, romańska, historia, fizyka, matematyka, ale też hebraistyka, indologia czy nauki o rodzinie.

\section{Wykr. 4. Kierunek studiów respondentów}

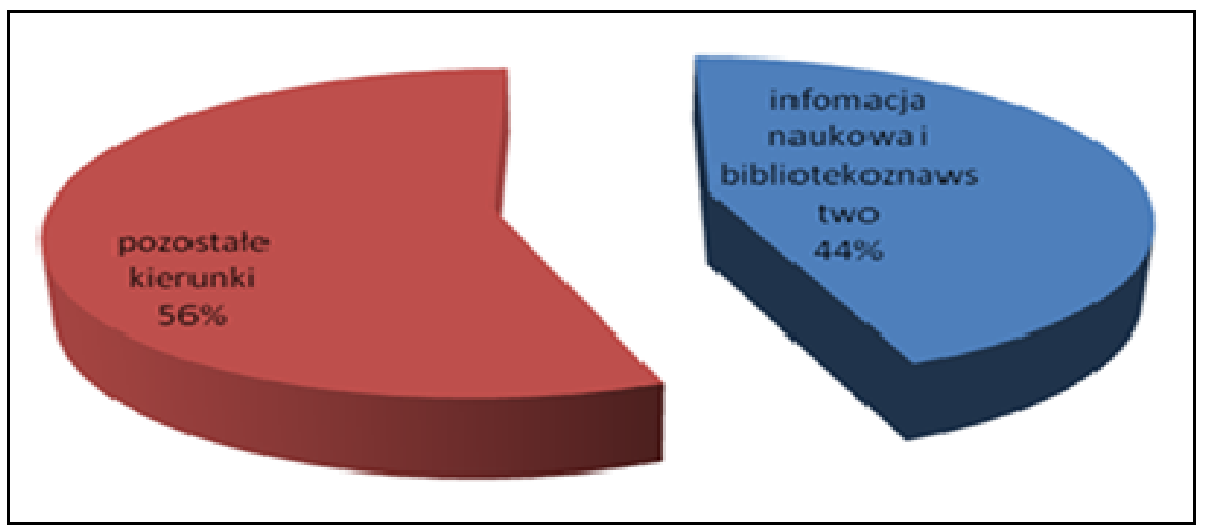

Źródło: opracowanie własne. 
Studenci odpowiedzieli na 35 pytań dotyczących oczekiwań jakości usług w bibliotece uniwersyteckiej. Respondenci mieli za zadanie określić, które aspekty usług są dla nich ważne, a które mniej albo wcale. Odpowiedzi udzielali w skali od 0 do 6 , gdzie $0=$ nieważne, a $6=$ bardzo ważne.

Pytania były podzielone na 8 kategorii. Dotyczyły: personelu biblioteki, materiałów dostarczanych przez bibliotekę, pomieszczeń placówki, mebli oraz sprzętu, formatów dokumentów z jakich można korzystać w bibliotece lub poza nią np.: na jej stronie internetowej, godzin otwarcia bibliotek oraz informacji o samej bibliotece, jej usługach i zasobach.

Zgodnie z wynikami ankiety, najważniejsze dla respondentów są: dobra znajomość zasobów biblioteki przez pracowników biblioteki (średnia 5,4) oraz dogodne godziny otwarcia biblioteki $(5,4)$. Najmniej ważne okazało się wizualnie atrakcyjne pomieszczenia biblioteki $(3,7)$, nowoczesny sprzęt w bibliotece $(3,9)$ oraz schludny i elegancki wygląd bibliotekarzy $(4,0)$. Decydujące dla studentów okazały się też (średnia 5,3) takie aspekty jak: dostarczanie materiałów przez pracowników w obiecanym czasie, umiejscowienie materiałów w odpowiednich miejscach na półkach, możliwość korzystania $\mathrm{z}$ baz on-line poza biblioteką oraz informacje o bibliotece, usługach i zasobach na stronie internetowej Biblioteki.

Dla grupy badanych istotne również (średnia 5,2) jest to, czy pracownicy są zawsze dostępni, empatyczni, grzeczni i pomocni, a materiały dostarczane przez bibliotekę odpowiadają potrzebom wynikającym ze studiów. Studenci podkreślają (średnia 5,1) nastawienie pracowników, czy są przyjaźni i komunikacyjni. Ważne okazuje się też to czy materiały dostarczane przez bibliotekę są aktualne i w odpowiedniej ilości, i czy katalogi nie zawierają błędów i są łatwe w obsłudze. Istotna jest również sprawność sprzętów w bibliotece.

Respondenci zwracali uwagę na szybki dostęp do nowych materiałów na półkach, dobrze oznakowane pomieszczenia biblioteki oraz możliwość korzystania z baz on-line w bibliotece (średnia 4,9). Studenci chcą też mieć możliwość korzystania z biblioteki w weekendy.

Badani wskazywali też i inne interesujące odpowiedzi: możliwości zrobienia ksero w przystępnej cenie $(4,8)$, informowanie przez pracowników o dostępności zamówionych materiałów $(4,7)$ oraz możliwość skorzystania $\mathrm{z}$ wydawnictw w językach obcych $(4,6)$. W następnej kolejności istotne jest czy pracownicy pokazują jak korzystać z katalogów oraz czy biblioteka jest czynna do późnych godzin wieczornych $(4,4)$ oraz czy można łatwo znaleźć wolne krzesło i stolik, szybki czas oczekiwania na usługę oraz przesyłanie ważnych informacji pocztą elektroniczną $(4,3)$.

Wedug studentów ważne jest również, czy pracownicy poświęcają użytkownikom indywidualną uwagę $(4,2)$, czy informuja, gdzie można znaleźć potrzebne materiały poza biblioteką, czy meble w placówce są wygodne 
i funkcjonalne oraz czy informacje o bibliotece, usługach i zasobach można znaleźć na tablicach informacyjnych $(4,1)$.

\section{Podział na studentów informacji naukowej i bibliotekoznawstwa oraz na studentów pozostałych kierunków}

Przeprowadzony został również podział wyników ankiety ze względu na oczekiwania studentów informacji naukowej i bibliotekoznawstwa oraz studentów pozostałych kierunków.

Dla studentów bibliotekoznawstwa najważniejsze są aspekty: dostępności materiałów w odpowiednich miejscach na półkach, godzin otwarcia zgodne z potrzebami użytkowników, dostępności informacji o bibliotece, zasobach i usługach w Internecie oraz dobrej znajomość zasobów biblioteki przez pracowników.

Z kolei dla studentów pozostałych kierunków najważniejsze jest to, czy pracownicy biblioteki znają dobrze zasoby biblioteki, czy można korzystać z baz on-line poza biblioteka, czy pracownicy biblioteki rozumieją potrzeby informacyjne czytelników i czy dostarczają materiały w zadeklarowanym czasie, a ponadto czy materiały są na odpowiednich miejscach na półkach oraz czy godziny otwarcia biblioteki dostosowane do potrzeb użytkowników.

Lista aspektów najmniej ważnych była u bibliotekoznawców oraz u studentów innych kierunków podobna. Najmniej liczyły się: wizualnie atrakcyjne pomieszczenia biblioteki $(3,7)$, nowoczesny sprzęt $\mathrm{w}$ bibliotece $(3,9)$, informacje o bibliotece, usługach i zasobach na tablicach informacyjnych $(4,0)$, empatia i schludny i elegancki wygląd pracowników $(4,0)$.

Porównując oczekiwania dotyczące jakości usług bibliotecznych studentów bibliotekoznawstwa i pozostałych kierunków, można stwierdzić, że różnią się w nieznacznej mierze. Aspekty najmniej ważne są takie same i u jednych, i u drugich. Różnice natomiast, choć niewielkie, można zauważyć w kategoriach uznawanych przez większość za ważne. Dla bibliotekoznawców najistotniejsza jest dostępność poszukiwanych materiałów, dogodne godziny otwarcia placówki oraz zamieszczone w Internecie informacje o zasobach i usługach. Dla studentów innych kierunków zdecydowanie na pierwszym miejscu jest znajomość zasobów przez personel placówki.

Różnice między oczekiwaniami mogą wynikać $\mathrm{z}$ toku studiów i wiedzy zdobytej w czasie ich trwania. Studenci bibliotekoznawstwa, w trakcie studiów i odbytych praktyk mają dużą wiedzą dotyczącą funkcjonowania różnego typu bibliotek, w tym uniwersyteckich oraz oferowanych przez nie usług. Potrafią poruszać się po katalogach oraz wyszukiwać niezbędne im informacje i dokumenty. Natomiast studenci innych kierunków jedyną wiedzę i doświadczenie mają z szkoleń bibliotecznych na I roku oraz indywidualnych odwiedzin w poszukiwaniu materiałów do nauki. 


\section{Wykr. 5. Hierarchia determinantów jakości usług}

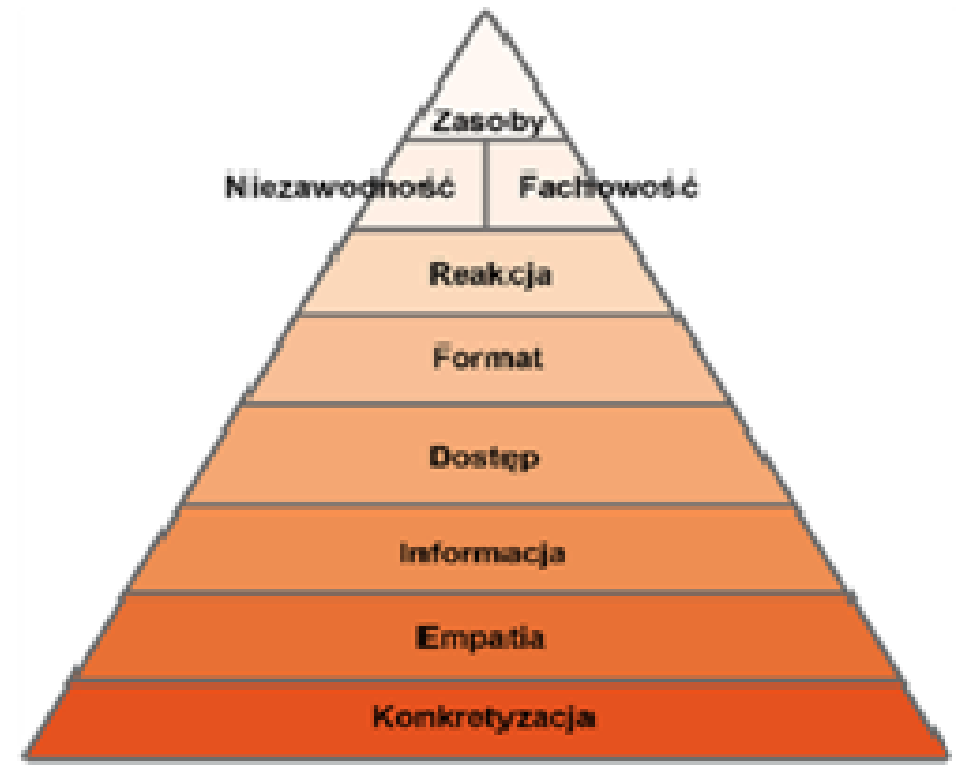

Źródło: opracowanie własne.

Jeżeli przyporządkujemy pytania do poszczególnych determinantów możemy stworzyć hierarchię determinantów postrzegania jakości usług. W tej hierarchii dla studentów UW znajdują się zasoby, czyli liczba materiałów oraz ich dostosowanie do programu studiów i potrzeb użytkowników. Następnie ważna jest niezawodność i fachowość pracowników, a także format, bazy on-line oraz dostępność w nich potrzebnych materiałów, jakie posiada biblioteka. Istotna jest też informacja o samej bibliotece, usługach i jej zasobach. A na samym końcu - empatia i konkretyzacja, czyli wygląd pracowników biblioteki, jej wyposażenie i nowoczesność sprzętu.

\section{Podsumowanie}

Pojęcie jakości pojawiło się już w starożytności. Tworząc powyższy artykuł nie stawiałyśmy sobie jednak za zadanie wyczerpująco opisać rozwoju oraz przemian, jakie przechodziło pojęcie jakości przez wieki - temu poświęcić trzeba by znacznie dłuższy tekst. Skupiłyśmy się, co zaznaczono w tekście artykułu, jedynie na miejscu terminu ,jakość” w teorii i nauce o zarządzaniu, których początki przypadają właśnie na początek XX wieku.

Literatura dotycząca badań jakości usług bibliotecznych jest niezwykle bogata i była dla nas inspiracją oraz źródłem dobrych praktyk przy tworzeniu powyższego tekstu. Do tej pory nie opublikowano jednak jeszcze badań 
przeprowadzonych w Bibliotece Uniwersytetu Warszawskiego metodą SERVQUAL, której to użyłyśmy w swoim badaniu. Ze względu na specyfikę tej metody postanowiłyśmy nie porównywać wyników naszych badań z wynikami przeprowadzonymi innymi metodami - byłoby to bardzo trudne do wykonania.

Aby biblioteka uniwersytecka była nie tylko miejscem, w którym studenci sieggaja po potrzebne im publikacje, ale także wielofunkcyjnym centrum informacji i kultury, musi ona zapewniać swoim użytkownikom wysokiej jakości usługi. W tym celu konieczne jest prowadzenie systematycznych, szeroko zakrojonych badań potrzeb, aby zakres usług pokrywał się z oczekiwaniami użytkowników. 